\title{
ESTIMATION OF POSTOPERATIVE CARDIAC COMPLICATIONS WITH V-POSSUM MODEL IN PATIENTS PREPARED FOR MAJOR ELECTIVE VASCULAR SURGERY
}

\author{
Mladjan Golubović1,2, Velimir Perić3, Milan Lazarević4, Nenad Jovanović1,2, \\ Vesna Marjanović1,3, Biljana Stošić1,3, Dragan Milić3,4
}

\begin{abstract}
The Vascular Physiological and Operative Severity Score for the enUmeration of Mortality and Morbidity (V-POSSUM) is a vascular surgical modification of POSSUM. The aim of the study is to investigate role of V-POSSUM in estimation of major adverse cardiac events (MACE) in patents after major elective vascular surgery. We also wanted to examine relationship of various clinical and demographic data with postoperative cardiac complications. We prospectively enrolled all 122 patients prepared for major open elective vascular surgery (abdominal aortic aneurysm repair, inferior inguinal arterial reconstruction, or carotid endarterectomy). The analysis of the Kaplan-Meier curve showed that patients with a morbidity assessment of V-POSSUM score $>27$ had a statistically significantly shorter time to develop cardiac complications in the first month compared to other patients $(p=0.026)$. Neither of clinical and demographic characteristics was not associated with postoperative cardiovascular events. V-POSSUM represents a way to improve the stratification for postoperative cardiac complications in patients prepared for major elective vascular surgery.

Acta Medica Medianae 2019;58(1):39-43.
\end{abstract}

Key words: V-POSSUM, cardiac complications, vascular surgery

\footnotetext{
${ }^{1}$ Clinic for Anesthesiology and Intensive therapy, Clinical Center Niš, Niš, Serbia

2University of Niš, Medical Faculty, Department for

Cardiosurgery, Niš, Serbia

${ }^{3}$ University of Niš, Medical Faculty, Niš, Serbia

${ }^{4}$ Clinic for Cardiovascular and Transplantational Surgery,

Clinical Center Niš, Niš, Serbia
}

Contact: Mladjan Golubović

Grčka 17, 18000 Niš, Serbia

E-mail: mladjangolubovic@gmail.com

\section{Introduction}

The Vascular Physiological and Operative Severity Score for the enumeration of Mortality and Morbidity (V-POSSUM), is a vascular surgical modification of POSSUM in which the original developers examined 62 physiological parameters and used muIti-variate analysis to identify the most powerful predictors of mortality. This eventually reduced the 62 to 12 physiological and 6 operative parameters. In the preoperative period only the 12 physiological parameters can be collected. The 12 physiological parameters required include age, evidence of cardiac failure (categorised based on current cardiac medication and on clinical evidence of heart failure), evidence of pulmonary disease (categorised based on severity of dyspnoea or evidence of consolidation), preoperative ECG changes (based on rate, ectopics, Qwaves and ST changes), systolic BP, resting pulse rate, Glasgow Coma Scale scoring, and serum levels of haemoglobin, white cell count, urea, sodium and potassium (1). These were placed into the online $\mathrm{V}$ POSSUM calculator at www.riskprediction.org.uk to calculate individual scores. The aim of the study is to investigate role of V-POSSUM in estimation of major adverse cardiac events (MACE) in patents after major elective vascular surgery. We also wanted to examine relationship of various clinical and demographic data with postoperative cardiac complications.

\section{Material and methods}

The study was approved by the Ethics Committee of Medical Faculty University of Nis, Serbia. During 2017, we prospectively enrolled all 122 patients prepared for major open elective vascular surgery (abdominal aortic aneurysm repair, infrainguinal arterial reconstruction, or carotid endarterectomy) in Clinic for Cardiovascular and Transplantation Surgery, Clinical Center Niš, Niš, Serbia. Exclusion criteria were: 1) patients younger than 21 years, 2) unstable coronary disease and 3) decompensated 
heart failure. All procedures were performed during general anesthesia. All patients initially underwent detail evaluation of medical history, physical examination, routine hematologic and biochemical blood analysis, 12-lead electrocardiogram, and chest radiography. We used online risk calculator software for V-POSSUM (http://www.riskprediction.org.uk/vascindex.php). During the 30-days after the procedure, major adverse cardiac events such as: myocardial infarction, ventricular arrhythmias, decompensating heart failure, and new onset atrial fibrillation were recorded.

\section{Statistical analysis}

The obtained data are entered into the database, arranged by tables and shown graphically. As part of descriptive statistics, data are presented in the form of arithmetic mean and standard deviation, median and interquartile differences, minimum and maximum values, or in the form of absolute or relative numbers. Testing of the normality of data is carried out by Kolmogorov-Smirnov test. For the com- parison of two groups of data, if a normal distribution was satisfied, a t-test was used, if the data distribution was not normal, Mann-Whitney's $U$ test was used. For the comparison of three or more data sets, if the normal distribution was satisfied, ANOVA was used, and the Tukey test was used as a post hoc analysis. If the normal distribution was not satisfied when comparing three or more data sets, a KruskalWallis test was used, in which case Mann-Whitney's $U$ test was used as a post hoc analysis. To compare the attributes, a Hi-square test, or Fisher's Exact Probability Test, was used. Statistical data processing was carried out in the SPSS 16.0 program package (SPSS Inc., Chicago, Ill., USA). Statistical significance was determined for a $p$ value of less than 0.05 .

\section{Results}

The study included 122 patients (94 men $77.0 \%$, 28 women $-23.0 \%$ ), average age $67.03 \pm$ 4.50 years (Min 48, Max 84 years) (Table 1 ).

Table 1. Clinical characteristics

\begin{tabular}{||lcl||}
\hline Characteristics & Number & \% \\
\hline \hline Atrial fibrillation & 6 & 4.9 \\
Earlier stroke & 32 & 26.2 \\
Coronary disease & 26 & 21.3 \\
Cardiomyopathy & 12 & 9.8 \\
Prior PCI & 7 & 5.7 \\
Earlier myocardial infarction & 21 & 17.2 \\
Earlier CABG & 2 & 1.6 \\
Hypertension & 104 & 85.2 \\
DM & 38 & 31.1 \\
DMID & 19 & 15.6 \\
Hyperlipidemia & 31 & 25.4 \\
Smoking & 49 & 40.2 \\
Family history of cardiac diseases & 49 & 40.2 \\
\hline \hline
\end{tabular}

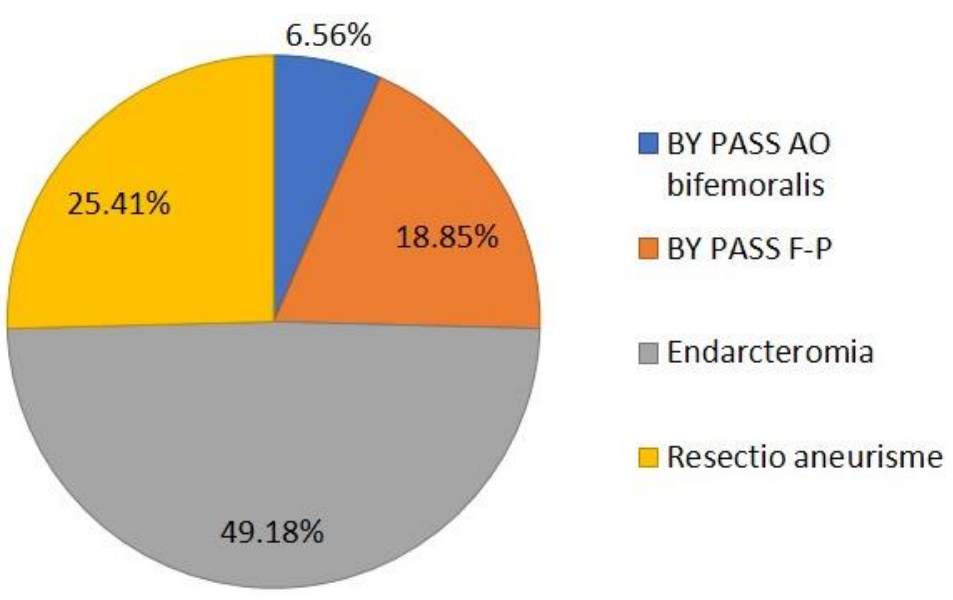

Graph 1. Representation of operative procedures 
In the investigated population 8 patients underwent open aortic (by-pass aorto - bifemoralis $(6.56 \%)), 23$ patients underwent open reconstruction of inferior inguinal (BY-PASS F-P (18.85\%)), 60 patients underwent open reconstruction of carotid artery $(49.18 \%)$, and 31 patients underwent resection of infrarenal aortic resection (By pass aorto-biiliacalis (25.41\%)) (Graph 1).

In the first 30 days after procedure 13 patients $(10,7 \%)$ had 17 cardiovascular complications (Table 2). The most common complication was the new onset of atrial fibrilation (35,3\%). Ten patients had one complication (76,9\%), two patients had two complications $(15,4 \%)$, and only one patient had three complications $(7,7 \%)$. Only one patient died as a consequence of myocardial infarction. We did not have patients with pulmonary artery thromboembolism.

The occurrence of cardiac complications (Table 3 ) in the first month is equal regardless of the age ( $p$ $=0,182)$, gender $(p=0,736)$, atrial fibrillation $(p=$ $1,000)$, stroke $(p=0,544)$, coronary artery disease $(p=0,601)$, cardiomyopathy $(p=0,229)$, prior PCI $(p=1,000)$, earlier myocardial infarction $(p=1,000)$, earlier CABG ( $p=0,797)$, hypertension ( $p=0,946)$, diabetes mellitus ( $p=0,775)$, insulin dependent diabetes mellitus $(p=0,700)$, hyperlipidemia ( $p=$ $0,895)$, smoking ( $p=0,868)$, family history of cardiac disease $(p=0,895)$.

Table 2. Cardiac complications during first month

\begin{tabular}{|lcl||}
\hline \hline Postoperative cardiac events & Number & \% \\
\hline Fatal myocardial infarction & 1 & 5.9 \\
Ventricular arrhytmias & 4 & 23.5 \\
CPR & 1 & 5.9 \\
Decompensation of heart failure & 5 & 29.4 \\
New onset of atrial fibrilation & 6 & 35.3 \\
Total & 17 & 100.0 \\
\hline \hline
\end{tabular}

Table 3. Relation of cardiac and demographic characteristics with postoperative cardiac complications in first postoperative month

\begin{tabular}{||lccccc||}
\hline \multirow{2}{*}{ Parametar } & \multicolumn{7}{l}{ Cardiac events } & Others & \\
\cline { 2 - 5 } & Number & $\%$ & Number & $\%$ & p-value \\
\hline Age & $69.08 \pm 5.47$ & $66.79 \pm 6.59$ & 0.182 \\
Gender & & & & & \\
Male & 11 & 84.6 & 83 & 76.1 & 0.736 \\
Female & 2 & 15.4 & 26 & 23.9 & \\
Atrial fibrillation & 1 & 7.7 & 5 & 4.6 & 1.000 \\
Stroke & 2 & 15.4 & 30 & 27.5 & 0.544 \\
Coronary disease & 4 & 30.8 & 22 & 20.2 & 0.601 \\
Cardiomyopathy & 3 & 23.1 & 9 & 8.3 & 0.229 \\
Prior PCI & 1 & 7.7 & 6 & 5.5 & 1.000 \\
Earlier MI & 2 & 15.4 & 19 & 17.4 & 1.000 \\
Earlier CABG & 0 & 0 & 2 & 1.8 & 0.797 \\
Hypertension & 11 & 84.6 & 93 & 85.3 & 0.946 \\
DM & 5 & 38.5 & 33 & 30.3 & 0.775 \\
DMID & 3 & 23.1 & 16 & 14.7 & 0.700 \\
Hyperlipidemia & 4 & 30.8 & 27 & 24.8 & 0.895 \\
Smoking & 6 & 46.2 & 43 & 39.4 & 0.868 \\
Family history of cardiac diseases & 5 & 38.5 & 44 & 40.4 & 0.895 \\
\hline
\end{tabular}

The distribution of various interventions is uniform in relation to the occurrence of cardiac complications (Table 4$)$ in the first month ( $p=0.607$ ). In both examined groups, open surgical reconstructions of carotid artery (endarterectomy) (38.5\% and $50.5 \%$ ) were most performed.
The analysis of the Kaplan-Meier curve showed that patients with a morbidity assessment of $\mathrm{V}$ POSSUM score $>27$ had a statistically significantly shorter time to develop cardiac complications in the first month compared to other patients $(p=0.026)$ (Table 5). 
Table 4. Impact of type of the surgery

\begin{tabular}{|c|c|c|c|c|c|}
\hline \multirow{2}{*}{ Type of the surgery } & \multicolumn{2}{|c|}{ Cardiac events } & \multicolumn{2}{|c|}{ Others } & \multirow{2}{*}{$\mathrm{p}^{1}$} \\
\hline & Number & $\%$ & Number & $\%$ & \\
\hline By pass Ao- bifemoralis & 2 & 15.4 & 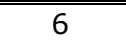 & 5.5 & 0,607 \\
\hline By pass F-P & 3 & 23.1 & 20 & 18.3 & \\
\hline Endarcteromia & 5 & 38.5 & 55 & 50.5 & \\
\hline By pass Ao-biiliacalis & 3 & 23.1 & 28 & 25.7 & \\
\hline
\end{tabular}

Table 5. Kaplan-Meier's curve of survival after cardiac complications in the first month compared to V-POSSUM values $>27$

\begin{tabular}{|cccc||}
\hline Characteristic & Average survival & SE & p-valuet \\
\hline \hline V-POSSUM & & & \\
$\mathbf{5} \mathbf{2 7}$ & 27.38 & 0.94 & 0.026 \\
$\mathbf{> 2 7}$ & 24.32 & 2.03 & \\
& & & \\
\hline † - log rank test, SE - standard error & &
\end{tabular}

\section{Discussion}

$\mathrm{V}$-POSSUM is a more reliable model then original POSSUM in the stratification of patients in vascular surgery (1). Its importance is known in the prediction of short-term mortality in elective and urgent major vascular surgery $(2,3)$. In this study, we wished to examine the role of V-POSSUM in the estimation of MACE. However, there is no unique definition of MACE. We define MACE as a large group of cardiovascular morbidities unlike in other definitions. Earlier our concern was to describe geographic variations in the accuracy of this model (4). We assumed that such good model characteristics in the prediction of mortality would have to be reflected in the assessment of postoperative cardiac complications. Neither of clinical and demographic characteristics was associated with postoperative cardiovascular events. A part of this group is independent predictors of major cardiac events, except renal failure, which is incorporated in Revised Cardiac Risk Index (RCRI). In this study, we could not determine the statistical significance of these factors. We consider it due to the fact that: 1) RCRI had a lower discriminatory potential for adverse cardiac events estimation; 2) narrow definition of MACE; 3) there was less than a quarter major vascular surgery patients (5). In this study, the patients with V-POSSUM > 27 had significantly shorter time to cardiovascular complications during the first month. A study that included a similar number of respondents as ours, in open elective abdominal aortic aneurysm repair, showed V-POSSUM as a valuable tool in stratification for MACE defined as a non-fatal myocardial infarction and cardiac death (6).

\section{Conclusion}

V-POSSUM represents a way to improve the stratification for postoperative cardiac complications in patients prepared for major elective vascular surgery.

\section{References}

1. Prytherch DR, Ridler BM, Beard JD, Earnshaw JJ. A model for national outcome audit in vascular surgery. Eur J Vasc Endovasc Surg 2001; 21(6):477-83. [CrossRef] [PubMed]

2. Harris $J R$, Forbes $T L$, Steiner $S H$, Lawlor DK, Derose G, Harris KA. Risk-adjusted analysis of early mortality after ruptured abdominal aortic aneurysm repair. ] Vasc Surg 2005; 42(3):387-91. [CrossRef] [PubMed]
3. Tang TY, Walsh SR, Prytherch DR, Wijewardena C, Gaunt ME, Varty K, et al. POSSUM Models in Open Abdominal Aortic Aneurysm Surgery. Eur J Vasc Endovasc Surg 2007; 34(5):499-504. [CrossRef] [PubMed]

4. Walsh SR, Prytherch DR, Wijewardena C, Gaunt ME, Varty K, Boyle JR. POSSUM models in open abdominal aortic aneurysm surgery. Eur J Vasc Endovasc Surg 2007; 34(5):499-504. [CrossRef] [PubMed] 
5. Lee TH, Marcantonio ER, Mangione CM, Thomas EJ, Polanczyk CA, Cook EF. Derivation and prospective validation of a simple index for prediction of cardiac risk of major noncardiac surgery. Circulation 1999; 100(10):1043-9. [CrossRef] [PubMed]
6. Bryce GJ, Payne CJ, Gibson SC, Kingsmore DB, Byrne DS, Delles C. Risk stratification scores in elective open abdominal aortic aneurysm repair: are they suitable for preoperative decision making? Eur J Vasc Endovasc Surg 2012; 44(1):55-61. [CrossRef] [PubMed]

\title{
PROCENA POSTOPERATIVNIH SRČANIH KOMPLIKACIJA POMOĆU V-POSSUM MODELA U PRIPREMI BOLESNIKA ZA VEĆE ELEKTIVNE VASKULARNE HIRURŠKE ZAHVATE
}

\author{
Mlađan Golubović1,2, Velimir Perić ${ }^{3}$, Milan Lazarević ${ }^{4}$, Nenad Jovanović ${ }^{1,2}$, \\ Vesna Marjanović1,3, Biljana Stošić1,3, Dragan Milićc,
}

${ }^{1}$ Klinika za anesteziologiju i intenzivnu terapiju; Klinički centar Niš, Niš, Srbija
${ }^{2}$ Univerzitet u Nišu, Medicinski fakultet, Katedra za kardiohirurgiju, Niš, Srbija
${ }^{3}$ Univerzitet u Nišu, Medicinski fakultet, Niš, Srbija
${ }^{4}$ Klinika za kardiovaskularnu i transplantacionu hirurgiju, Klinički centar Niš, Niš, Srbija

Kontakt: Mlađan Golubović

Grčka 17, 18000 Niš, Serbia,

E-mail: mladjangolubovic@gmail.com

Vaskularna fiziološka i operativna ocena težine za računanje mortaliteta i morbiditeta (V-POSSUM) je vaskularna hirurška modifikacija POSSUM-a. Cilj studije bio je istraživanje uloge V-POSSUM-a u proceni glavnih neželjenih srčanih manifestacija kod pacijenata nakon velikih elektivnih vaskularnih operacija. Takođe, želeli smo da ispitamo odnos različitih kliničkih i demografskih podataka sa postoperativnim srčanim komplikacijama. Prospektivno smo uključili 122 bolesnika, koji su pripremani za veliku vaskularnu hirurgiju (aneurizma abdominalne aorte, inferiorna ingvinalna arterijska rekonstrukcija ili karotidna endarterektomija). Analiza Kaplan-Majerove krivulje pokazala je da su bolesnici sa procenom morbiditeta skor VPOSSUM > 27, imali statistički značajno kraće vreme za razvoj srčanih komplikacija u prvom mesecu u poređenju sa drugim bolesnicima $(p=0,026)$. Nijedna klinička i demografska karakteristika nije bila povezana sa postoperativnim kardiovaskularnim događajima. V-POSSUM predstavlja način da se poboljša stratifikacija postoperativnih srčanih komplikacija kod bolesnika pripremljenih za veliku elektivnu vaskularnu operaciju.

Acta Medica Medianae 2019;58(1):39-43.

Ključne reči: V-POSSUM, srčane komplikacije, vaskularna hirurgija 